\title{
Bruk av antibiotika i svangerskapet
}

\begin{abstract}
BAKGRUNN Antibiotika er de reseptpliktige legemidler som er mest brukt i svangerskapet. Det er derfor viktig å undersøke om antibiotikabruk under graviditet kan gi forsterskade. Det siste tiåret har tilgjengeligheten til data fra nasjonale registre gjort det mulig å gjennomføre store epidemiologiske studier. Formålet med denne artikkelen var å gjennomgå nyere studier om risiko for medfødte misdannelser og spontanabort ved bruk av antibiotika i svangerskapet.
\end{abstract}

KUNNSKAPSGRUNNLAG Det ble gjort et litteratursøk i Medline, Embase og PubMed for perioden 1.12. 2005-1.12. 2015. Vi identifiserte 1316 artikler. 23 av disse fylte inklusjonskriteriene.

RESULTATER I nyere epidemiologiske studier har man særlig undersøkt risiko for misdannelser og risiko for pylorusstenose etter eksponering for makrolider, nitrofurantoin, penicilliner og trimetoprim-sulfapreparater. I ni av ti studier med til sammen over 38000 kvinner eksponert for makrolider og i to studier med over 7000 eksponert for nitrofurantoin ble det ikke funnet noen signifikant $ø$ kt risiko for misdannelser. For enkelte grupper antibiotika foreligger det noe motstridende funn med hensyn til risikoen for spontanabort, hjertemisdannelser og pylorusstenose.

FORTOLKNING Nyere studier tyder på at erytromycin og nitrofurantoin kan brukes som annenhåndsvalg i første trimester. Anbefalingene til gravide i de nasjonale retningslinjene for antibiotikabruk i primærhelsetjenesten er i overensstemmelse med resultatene fra nyere studier.

Av reseptpliktige legemidler er det antibiotika som er mest brukt av gravide (1). I perioden $2004-06$ hentet $44 \%$ av alle førstegangsgravide i Norge ut minst én resept på slike midler i tiden tre måneder før til og med tre måneder etter svangerskapet (1). Penicilliner utgjorde over $70 \%$ av alle antibiotika som ble brukt av gravide, etterfulgt av makrolider, som utgjorde ca. $20 \%$ (1).

I 1950-årene erfarte man at enkelte antibiotika var skadelig for fostre og nyfødte. Sulfafurazol og kloramfenikol førte til henholdsvis en alvorlig form for gulsott og cyanotiske spedbarn (grey baby syndrome), og mange nyfødte døde (2).

Nahum og medarbeidere publiserte i 2006 en omfattende litteraturgjennomgang omkring sikkerheten ved 11 vanlige antibiotika brukt i svangerskapet (3). De fant ingen entydig sammenheng mellom bruk under graviditet og risiko for fosterskader eller spontanabort for de undersøkte antibiotika.

Risikoen ved bruk i svangerskapet ble vurdert som «ingen» (fenoksymetylpenicillin), «lite sannsynlig» (amoksicillin, kloramfenikol, ciprofloksacin, doksysyklin, levofloksacin og rifampin) eller «ukjent» (klindamycin, gentamicin og vankomycin). Kunnskapsgrunnlaget ble vurdert som «godt» (penicilliner utenom amoksicillin), "relativt godt» (amoksicillin, kloramfenikol, ciprofloksacin, doksysyklin, levofloksacin og rifampin), «begrenset» (klindamycin og gentamicin) og «svært begrenset» (vankomycin). Makrolider ble ikke vurdert. Denne studien har vært toneangivende for retningslinjer om bruk av antibiotika i svangerskapet, også for de norske nasjonale retningslinjene for antibiotikabruk i primærhelsetjenesten (4).

De siste ti årene er det publisert flere store epidemiologiske studier om sikkerheten ved antibiotikabruk i svangerskapet. Det er derfor et behov for å oppsummere nyere kunnskap. Hensikten med denne artikkelen var å gjennomgå studier fra perioden 1.12. 20051.12. 2015 som omhandlet risikoen for medfødte misdannelser og spontanabort ved bruk av antibiotika i svangerskapet.

\section{Kunnskapsgrunnlag}

Det ble foretatt et litteratursøk i Medline og Embase for perioden 1.12. 2005-1.9. 2014 med MeSH-termer (Medical Subject Heading) og fritekstord for antibiotika omtalt i kapitlet Gravide og ammende i Nasjonale faglige retningslinjer for antibiotika $i$ primorhelsetjenesten (4). Et oppdatert søk ble gjort for perioden 2.9. 2014-1.12. 2015. Dette førte til at to nye artikler ble inkludert $(5,6)$. Det ble da også søkt i PubMed, fordi denne databasen har kortere publiseringstid og dermed får med de nyeste studiene. Litteraturgjennomgangen ble utført i henhold til Preferred reporting items for systematic reviews and meta-analyses: the PRISMA statement fra 2009 (7). Søkestrengen er beskrevet i ramme 1 .

Litteratursøket ga i alt 1316 treff. Samtlige sammendrag ble gjennomgått, og 20 artikler ble inkludert $\mathrm{i}$ henhold til inklu-

\author{
Stina Nordeng \\ stnorden@studmed.uio.no \\ Det medisinske fakultet \\ Universitetet i Oslo
}

\section{Hedvig Nordeng}

Pharmacoepidemiology and Drug Safety Research Group (PharmaSafe)

Farmasøytisk institutt

Det matematisk-naturvitenskapelige fakultet Universitetet i Oslo

\section{Sigurd Høye}

Antibiotikasenteret for primærmedisin

Avdeling for allmennmedisin

Institutt for helse og samfunn

Det medisinske fakultet

Universitetet i Oslo

e-tab 1 finnes $i$ Tidsskriftets elektroniske utgaver

\section{HOVEDBUDSKAP}

Nyere epidemiologiske studier av høy kvalitet har gitt sikrere kunnskap om risikoen ved bruk av antibiotika under graviditeten

Det er godt grunnlag for å hevde at de fleste typer antibiotika trygt kan brukes i hele eller deler av svangerskapet

Selv om noen få studier kan indikere det motsatte, tyder hovedvekten av studiene på at bruk av erytromycin og nitrofurantoin i første trimester ikke gir økt risiko for fosterskade 


\section{RAMME 1}

\section{Beskrivelse av søkestrengen}

$\mathrm{MeSH}$-termer som ble brukt var: Anti-Bacterial Agents/or exp Anti-Infectives, urinary/and exp «Congenital, hereditary, and neonatal diseases and abnormalities»/or exp «Embryonic and Fetal Development»/or exp Pregnancy Complications, Infectious/or exp Abortion, spontaneous/or exp Fetal Death/or exp Fetal Diseases/ or exp Prenatal Injuries/ or exp Stillbirth/

Fritekstord for antibiotika oppgitt i Nasjonale faglige retningslinjer for antibiotika i primærhelsetjenesten hos gravide: penicillins/ or penicillin v/ or cloxacillin/ or dicloxacillin/ or amoxicillin/ or ampicillin/ or pivampicillin/ or pivmecillinam/ or cephalexin/ or cephalosporins/or lincosamides/or clindamycin/ or lincomycin/ or tetracyclines/or tetracycline/ or doxycycline/ or macrolides/ or erythromycin/ or azithromycin/ or clarithromycin/ or spiramycin/ or chloramphenicol/or quinolones/or ciprofloxacin/ or ofloxacin/ or metronidazol/ or trimethoprim-sulfamethoxazole combination/ or trimethoprim/ or sulfamethoxazole/ or nitrofurantoin/ or fluoroquinolones/ or beta-lactams/

Søket ble avgrenset til «human», «female» og «pregnancy». Språk ble begrenset til engelsk, norsk, dansk, svensk, tysk og fransk

\section{RAMME 2}

Inklusjonskriterier:

Alle studier med data om forekomst av fosterskader, spontanabort eller dødfødsel etter bruk av antibiotika i svangerskapet

\section{Ekslusjonskriterier:}

Kasuistikker, lederartikler, kommentarer og studier på effekt av antibiotika, antibiotika administrert i sykehus eller på antibiotika som ikke er markedsført i Norge

sjons- og ekslusjonskriteriene (ramme 2). I tillegg ble en artikkel fra PubMed inkludert samt to studier etter gjennomgang av referansene til de utvalgte artiklene. Figur 1 gir en oversikt over prosessen i litteratursøket.

Risikoen for systematiske feil i resultatene ble vurdert for hver enkelt artikkel i henhold til Nasjonalt kunnskapssenter for helsetjenestens sjekklister for kohort- og pa- sient-kontroll-studier (8). Studiens kvalite ble vurdert som høy hvis fire eller fem av totalt fem kriterier fra sjekklisten var oppfylt. Kvaliteten ble vurdert som middels hvis to eller tre av kriteriene var oppfylt og som lav hvis kun én eller ingen av kriteriene fra sjekklisten var oppfylt. Vurderingene ble utført av to av forfatterne (SN og HN) uavhengig av hverandre, og resultatene diskutert til konsensus ble oppnådd.

\section{Resultater}

I e-tabell $1(5,6,8-30)$ vises resultatene fra de 23 studiene som ble inkludert i denne oversikten. Det var 16 kohortstudier og syv pasient-kontroll-studier.

\section{Makrolider}

Siden 2006 er det publisert ti studier med over 38000 gravide som har vært eksponert for makrolider. Søkelyset har vært satt på faren for alvorlige strukturelle misdannelser. Fire av studiene er basert på skandinaviske helseregistre (9-12). I syv av de ti studiene fant man ingen sammenheng mellom bruk av makrolider og medfødte misdannelser eller spontanabort $(3,12-17,31)$. Derimot var det i én stor studie basert på det svenske fødselsregisteret en signifikant $ø$ kt risiko for kardiovaskulære misdannelser etter bruk av erytromycin i første trimester sammenlignet med resten av fødepopulasjonen (43 erytromycineksponerte barn med hjertemisdannelser av totalt 2531 erytromycineksponerte barn, OR $=1,70 ; 95 \% \mathrm{KI} 1,26-2,39)(10)$.

I en dansk studie med 401 klaritromycineksponerte kvinner ble det påvist signifikant økt risiko for spontanabort etter bruk av midlet i første trimester $(\mathrm{OR}=1,56 ; 95 \% \mathrm{KI}$ 1,14-2,13) sammenlignet med fenoksymetylpenicillin og erytromycin, der det ikke var noen signifikant økt risiko (9). I en annen studie fra Danmark med over 25000 eksponerte fant man en signifikant økt risiko for pylorusstenose ved bruk av erytromycin tatt i tiden mellom uke 28 og fødselen (OR $=2,24 ; 95 \%$ KI $1,20-4,18)(11)$.

\section{Penicilliner}

I to pasient-kontroll-studier var penicillineksponering undersøkt. Den første, med over 1300 pasienter, identifiserte en signifikant økt risiko for åpen leppe-gane-spalte etter bruk av amoksicillin i første trimester $(\mathrm{OR}=2,0 ; 95 \%$ KI $1,0-4,1)$ og i tredje svangerskapsmåned $(\mathrm{OR}=4,3 ; 95 \% \mathrm{KI}$ 1,4-13,0) og en signifikant økt risiko for isolert ganespalte etter bruk av amoksicillin i tredje svangerskapsmåned $(\mathrm{OR}=7,1 ; 95 \%$ KI 1,4-36) (18). Funnene var basert på 28 amoksicillineksponerte tilfeller av åpen leppe-gane spalte og 11 tilfeller av isolert ganespalte etter amoksicillineksponering $\mathrm{i}$ første trimester. Det var ikke forhøyet risiko etter bruk av andre penicilliner og kefalosporiner.

I den andre studien fant man også signifikant økt risiko for åpen leppe-gane-spalte etter bruk av amoksicillin i andre og tredje svangerskapsmåned $(\mathrm{OR}=15,9 ; 95 \% \mathrm{KI}$ 4,9-51,2) (19). Dette resultatet var basert på syv amoksicillineksponerte tilfeller av åpen leppe-gane-spalte.

I en dansk kohortstudie der man undersøkte flere antibiotika samtidig, fant man en mulig sammenheng mellom bruk av pivmecillinam i første trimester og isolert ganespalte $(\mathrm{OR}=2,36 ; 95 \%$ KI 1,2-4,6) (20). Den underliggende infeksjonen nevnes som mulig årsak, da det i studien ikke var inkludert en sykdomskontrollgruppe.

\section{Trimetoprim og sulfametoksazol}

Det ble identifisert to studier der eksponering for trimetoprim og/eller sulfametoksazol er undersøkt $(21,22)$. Den ene viste at det er signifikant økt risiko for spontanabort etter eksponering for trimetoprim i første trimester $(\mathrm{OR}=2,0 ; 95 \% \mathrm{KI} 1,4-2,9)$, den andre at det er signifikant økt risiko for prematuritet $(\mathrm{OR}=1,5 ; 95 \%$ KI 1,1-2,1) og lav fødselsvekt $(\mathrm{OR}=1,7 ; 95 \% \mathrm{KI} 1,1-2,9)$ etter eksponering for trimetoprim/sulfametoksazol. Dette gjelder under hele svangerskapet og er kjent fra tidligere $(3,31)$.

I tillegg fant man $\mathrm{i}$ en tredje studie der flere antibiotikagrupper ble undersøkt en signifikant økt risiko for isolert ganespalte etter bruk av trimetoprim i første trimester (20). Dette funnet var basert på to eksponerte tilfeller.

\section{Nitrofurantoin}

Etter 2006 er det publisert to studier der man har undersøkt sammenhengen mellom nitrofurantoin i første trimester og negative svangerskapsutfall, én av dem er basert på norske data $(23,24)$. I den norske studien identifiserte man en mulig sammenheng mellom bruk av nitrofurantoin den siste måneden $\mathrm{i}$ svangerskapet og gulsott hos nyfødte (24). Forfatterne anså at funnet var biologisk plausibelt, i og med at nitrofurantoin kan føre til hemolytisk anemi hos nyfødte. I den andre studien fant man ingen signifikant $ø \mathrm{kt}$ risiko for alvorlige misdannelser.

I en amerikansk pasient-kontroll-studie der man undersøkte flere antibiotikagrupper, ble det konkludert at nitrofurantoin muligens var forbundet med kardiovaskulære misdannelser ved eksponering i første trimester (25). Indikasjonen for bruken var ikke oppgitt og nevnes av forfatterne som en viktig begrensning i studien.

\section{Kinoloner}

Vi fant tre studier der kinoloner ble undersøkt $(6,25,26)$. Det var ingen signifikant økt 
risiko for alvorlige misdannelser eller spontanabort.

\section{Andre antibiotika}

Det ble ikke funnet noen studier der tetrasykliner, kefalosporiner og metronidazol alene ble undersøkt. Derimot ble disse antibiotikagruppene undersøkt i seks studier der man tok for seg flere antibiotika $(19,20$, 25-28). Ingen signifikant økt risiko for misdannelser eller lav fødselsvekt ble funnet for kefalosporiner (25-28) eller metronidazol $(19,26,28)$. Derimot ble det i to studier med barn med åpen leppe-gane-spalte identifisert signifikant økt risiko for slik skade etter eksponering for tetrasykliner $(19,20)$. I den ene studien var funnet basert på to eksponerte tilfeller (20).

$\mathrm{Vi}$ fant ingen noen nyere studier som omhandlet linkosamider eller kloramfenikol.

\section{Diskusjon}

Etter 2006 er det blitt publisert et tyvetalls epidemiologiske studier om risiko for fosterskader og spontanabort ved bruk av antibiotika i svangerskapet. De fleste er basert på store nasjonale helseregistre med mulighet til å inkludere sykdomskontrollgrupper og til å justere effektestimatene for viktige konfunderende faktorer som komorbiditet, sosioøkonomiske forhold og livsstilvaner. Dette har åpnet for epidemiologiske studier av høy kvalitet og med høy statistisk styrke. I enkelte studier er det fortsatt metodologiske begrensninger - de viktigste er lav statistisk styrke ved sjeldne utfall, manglende sykdomskontrollgruppe og manglende validering av antibiotikaeksponering og svangerskapsutfall.

Forekomsten av spesifikke misdannelser, slik som hjertefeil $(0,7 \%)$, åpen leppe-ganespalte $(0,2 \%)$ eller pylorusstenose $(0,1 \%)$, er lav (32). Det trengs derfor minst 1200 antibiotikaeksponerte gravide og 8000 kontrollpersoner for å avdekke en dobling av risikoen for hjertefeil med adekvat statistisk styrke (33). Dette betyr at man i de aller fleste studiene må ta forbehold om at man ikke kan utelukke en liten økt risiko for misdannelser selv om forskjellene ikke er statistisk signifikante. Det er viktig å være klar over slike usikkerhetsmomenter når resultatene fortolkes.

Tre kriterier må være til stede før funn fra studier om effekter på fosteret av kvinnens legemiddelbruk kan fortolkes som kausale: Det må finnes en biologisk plausibel forklaring på funnet, det må finnes en plausibel tidsrelasjon mellom antibiotikaeksponeringen og fosterskaden (legemidler gir for eksempel ikke opphav til strukturelle misdannelser som åpen leppe-gane-spalte etter slutten av første trimester) og den observerte sammenhengen må kunne reproduseres $\mathrm{i}$

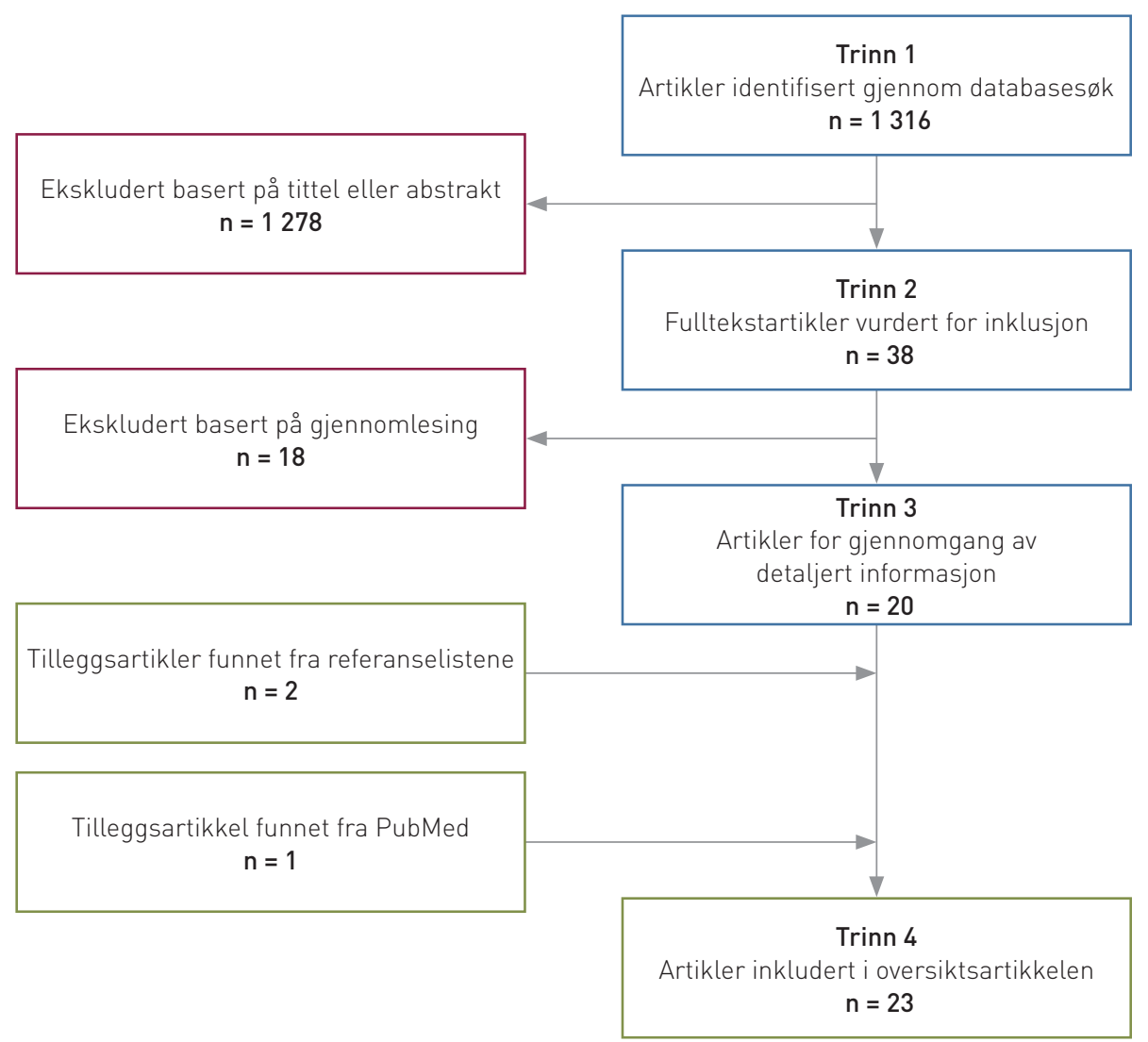

Figur 1 Litteratursøket og inklusjons-og eksklusjonskriterier

minst to epidemiologiske studier av høy kvalitet (34).

Et område som illustrerer nettopp denne problematikken, er risikoen for hjertefeil etter eksponering for makrolider i første trimester. Mens nyere norske data med nærmere 1800 eksponerte i første trimester (12) var i samsvar med de fleste andre studier av makrolider, som ikke viser signifikant økt risiko (12, $13,15,18,20,25-27)$, fant man i én svensk studie nesten en dobling av tilfeller av hjertefeil etter eksponering for erytromycin tidlig $i$ svangerskapet (10). I hovedsak dreide det seg om milde septumdefekter. Det ble ikke tatt hensyn til prematuritet eller spontan tilheling. Det ble heller ikke inkludert en kontrollgruppe der andre antibiotika var brukt, slik at en mulig effekt av den underliggende infeksjonen ikke kan utelukkes. Forfatterne av den svenske studien har tidligere foreslått at evnen makrolider har til å blokkere en spesiell kaliumkanal i hjertet (hERG-kanaler) kunne være en plausibel teratogen meksmisme (35), noe andre har trukket i tvil (36). På bakgrunn av hovedvekten av data, inkludert norske, og fordi den biologiske plausibiliteten er diskuterbar, mener vi makrolider bør kunne være annenhåndsvalg, altså i de tilfellene førstehåndsvalget ikke kan brukes på grunn av allergi eller andre kontraindikasjoner.
Et annet område med motstridende resultater er risikoen for hypertrofisk pylorusstenose ved bruk av makrolider sent i svangerskapet. I studien som viste en slik sammenheng, ble det justert for viktige konfunderende faktorer (slik som røyking) samt at det ble inkludert en sykdomskontrollgruppe med penicilliner, der det ikke ble vist signifikant økt risiko (11). Dette styrker sannsynligheten for at det var makrolideksponeringen som var årsaken til pylorusstenosen, ikke den underliggende infeksjonen. Resultatene tilsier derfor at man bør utvise forsiktighet ved bruk av makrolider de to siste månedene før termin.

De to studiene der man fant signifikant $ø k t$ risiko for åpen leppe-gane-spalte etter bruk av amoksicillin i første trimester, var basert på et lite antall eksponerte og på retrospektive pasientintervjuer (dvs. at informasjon om antibiotikabruk var samlet inn flere måneder etter fødselen) (19). Dermed er det risiko for rapporteringsskjevhet, dvs. at mødre med barn med fosterskader i større grad husker å rapportere om legemiddelbruk enn mødre med friske barn gjør. Vi fester derfor lite lit til disse resultatene.

I den danske studien der man undersøkte flere antibiotikagrupper, var det en signifikant økt risiko for isolert ganespalte etter bruk av pivmecillinam og trimetoprim og en signifikant $ø k t$ risiko for åpen leppe-gane- 


\begin{tabular}{|l|l|l|l|}
\hline Legemiddelgruppe & 1. trimester & 2. trimester & 3. trimester \\
\hline Penicilliner & & & \\
\hline Kefalosporiner & & & \\
\hline Linkosamider & & \\
\hline Tetrasykliner & & \\
\hline Makrolider & & \\
\hline Kloramfenikol - lokalbehandling øye & & \\
\hline Kinoloner & & \\
\hline Metronidazol & & \\
\hline Trimetoprim & & \\
\hline Sulfametoksazol & & \\
\hline Nitrofurantoin & & \\
\hline
\end{tabular}

'Det foreligger mindre dokumentasjon for de nyeste kefalosporinene

Kan brukes

Ingen holdepunkter for risiko i svangerskapet

Annenhåndsvalg til gravide

Motstridende epidemiologiske resultater og en virkningsmekanisme som kan gi grunnlag for tilbakeholdenhet med bruk i svangerskapet

Kontraindisert

Epidemiologiske resultater og/eller en virkningsmekanisme som tilsier økt risiko for fosterskade

Figur 2 Anbefalinger for de mest brukte antibiotika i primærhelsetjenesten til gravide

spalte etter bruk av doksysyklin/tetrasyklin og sulfametizol i første trimester (20). Resultatene var basert på to tilfeller hver med doksysyklin/tetrasyklin og trimetoprim og er derfor meget usikre, noe som gjenspeiles i svært brede konfidensintervaller rundt effektestimatene. For pivmecillinam og sulfametizol kan funnene muligens knyttes til den underliggende infeksjonen. Studien hadde ingen sykdomskontrollgruppe for å kontrollere for nettopp dette. I grundige studier fra før 2006 har man ikke funnet noen slik sammenheng (37-39). Vi anser derfor fortsatt pivmecillinam som trygt.

Norske retningslinjer for bruk av antibiotika i svangerskapet (4) og internasjonal litteratur (40) anbefaler restriksjoner når det gjelder tidspunkt for bruk av trimetoprim under graviditeten (folatantagonist), tetrasykliner (inkorporasjon i beinvev og tannemalje) og sulfonamider (fortrenging av bilirubinutskilling) på bakgrunn av virkningsmekanismene, som tilsier at det er en reell risiko for medfødte misdannelser i enkelte deler av svangerskapet (fig 2).

En av de andre studiene der man også undersøkte flere antibiotikagrupper, konkluderte med at nitrofurantoin og sulfonamider muligens var forbundet med medfødte misdannelser (25). Viktige begrensninger i denne studien var rapporteringsskjevhet, fordi kvinnene ble spurt om antibiotikabruk opptil 24 måneder etter fødselen og 35\% ikke kunne huske navnet på legemidlet de hadde tatt. Det ble heller ikke tatt hensyn til indikasjonen, noe som gjorde det vanskelig å vite om fosterskaden skyldtes legemidlet eller den underliggende infeksjonen.

Risiko for spontanabort etter antibiotikabruk ble undersøkt i syv av studiene $(9,14$, $15,17,21,29)$. I de tre danske der man fant signifikant økt risiko for spontanabort, var det ikke kontrollert for infeksjon etter bruk av en rekke antibiotika (klaritromycin, pivmecillinam, sulfametizol, trimetoprim). Dermed kan det ikke utelukkes at det var den underliggende infeksjonen som var årsaken til spontanabort. I de fire studiene der det ble kontrollert for infeksjon, fant man ingen signifikant økt risiko for spontanabort.

Alt $\mathrm{i}$ alt er det gode holdepunkter for å hevde at de fleste vanlige antibiotika trygt kan brukes under graviditet, dog avhengig av når (fig 2). Når det hos en gravid foreligger en behandlingskrevende infeksjon, er det viktig at hun er trygg på at hun bør etterleve antibiotikaregimet. Gravide har noen ganger en urealistisk oppfatning av hvor farlig legemidler er for fosteret, det gjelder også trygge antibiotika som penicilliner (41). Enkelte velger å ta abort på grunn av frykt for å få et barn med misdannelser $(14,15)$.

De norske retningslinjene for antibiotikabruk i primærhelsetjenesten ble oppdatert høsten 2015 og samsvarer godt med våre resultater. De er også i tråd med anbefalingene i UpToDate $(42,43)$ og BestPractice (44).

Denne kunnskapsoppsummeringen har enkelte begrensninger. Antibiotika som primært administreres i sykehus og antibiotika som ikke er markedsført i Norge, er ikke inkludert. I tillegg har vi denne litteraturgjennomgangen lagt hovedvekt på umiddelbare svangerskapsutfall. Studier på mulige langtidskonsekvenser for barnets helse, for eksempel astma (45) og epilepsi (46), ble ikke inkludert.

\section{Konklusjon}

Det er viktig at gravide med behandlingstrengende infeksjoner får adekvat behandling med antibiotika. Nyere epidemiologiske studier har gitt sikrere kunnskap om risikoen ved bruk av antibiotika i svangerskapet, og det er vist at de fleste typer antibiotika trygt kan brukes under hele eller deler av graviditeten.

\section{Stina Nordeng (f. 1974)}

er siviløkonom, har en mastergrad i økonomi og administrasjon fra ESCP-EAP i Paris og er medisinstudent.

Forfatteren har fylt ut ICMJE-skjemaet og oppgir ingen interessekonflikter.

\section{Hedvig Nordeng (f. 1972)}

er cand.pharm., dr.philos. og professor. Hun er leder for forskningsgruppen PharmaSafe og forfatter av kapitlet Gravide og ammende i Nasjonale faglige retningslinjer for antibiotikabruk i primærhelsetjenesten.

Forfatteren har fylt ut ICMJE-skjemaet og oppgir ingen interessekonflikter.

\section{Sigurd Høye (f. 1972)}

er postdoktorstipendiat og medisinsk redaktør i Tidsskriftet. Han er med i redaksjonen for Nasjonale faglige retningslinjer for antibiotikabruk i primærhelsetjenesten.

Forfatteren har fylt ut ICMJE-skjemaet og oppgir ingen interessekonflikter.

\section{Litteratur}

1. Engeland A, Bramness JG, Daltveit AK et al. Prescription drug use among fathers and mothers before and during pregnancy. A population-based cohort study of 106,000 pregnancies in Norway 2004-2006. Br J Clin Pharmacol 2008; 65: 653-60.

2. Mclntyre J, Choonara I. Drug toxicity in the neonate. Biol Neonate 2004; 86: 218-21.

3. Nahum GG, Uhl K, Kennedy DL. Antibiotic use in pregnancy and lactation: what is and is not known about teratogenic and toxic risks. Obstet Gynecol 2006; 107: 1120-38

4. Helsedirektoratet. Nasjonale faglige retningslinjer for antibiotikabruk i primærhelsetjenesten. 2015. www.antibiotikaiallmennpraksis.no (21.12.2015). 
5. Bérard A, Sheehy O, Zhao JP et al. Use of macrolides during pregnancy and the risk of birth defects: a population-based study. Pharmacoepidemiol Drug Saf 2015; 24: 1241-8.

6. Padberg S, Wacker E, Meister R et al. Observational cohort study of pregnancy outcome after firsttrimester exposure to fluoroquinolones. Antimicrob Agents Chemother 2014; 58: 4392-8.

7. Moher D, Liberati A, Tetzlaff J et al. Preferred reporting items for systematic reviews and metaanalyses: the PRISMA Statement. Open Med 2009; 3: e123-30.

8. Nasjonalt kunnskapssenter for helsetjenesten. Sjekklister for vurdering av forskningsartikler. www.kunnskapssenteret.no/verktoy/sjekklisterfor-vurdering-av-forskningsartikler (12.2.2015).

9. Andersen JT, Petersen M, Jimenez-Solem E et al. Clarithromycin in early pregnancy and the risk of miscarriage and malformation: a register based nationwide cohort study. PLOS ONE 2013; 8 : e53327.

10. Källén B, Danielsson BR. Fetal safety of erythromycin. An update of Swedish data. Eur J Clin Pharmacol 2014; 70: 355-60

11. Lund M, Pasternak B, Davidsen RB et al. Use of macrolides in mother and child and risk of infantile hypertrophic pyloric stenosis: nationwide cohort study. BMJ 2014; 348: g1908.

12. Romøren M, Lindbæk M, Nordeng H. Pregnancy outcome after gestational exposure to erythromycin - a population-based register study from Norway. Br J Clin Pharmacol 2012; 74: 1053-62.

13. Bahat Dinur A, Koren G, Matok I et al. Fetal safety of macrolides. Antimicrob Agents Chemother 2013: 57: 3307-11.

14. Bar-Oz B, Diav-Citrin O, Shechtman S et al. Pregnancy outcome after gestational exposure to the new macrolides: a prospective multi-center observational study. Eur J Obstet Gynecol Reprod Biol 2008: 141: $31-4$

15. Bar-Oz B, Weber-Schoendorfer C, Berlin M et al. The outcomes of pregnancy in women exposed to the new macrolides in the first trimester: a prospective, multicentre, observational study. Drug Saf 2012; 35: 589-98.

16. Lin KJ, Mitchell AA, Yau WP et al. Safety of macrolides during pregnancy. Am J Obstet Gynecol 2013: 208: 221.e1-8.

17. Sarkar M, Woodland C, Koren G et al. Pregnancy outcome following gestational exposure to azithromycin. BMC Pregnancy Childbirth 2006; 6: 18.

18. Lin KJ, Mitchell AA, Yau WP et al. Maternal exposure to amoxicillin and the risk of oral clefts. Epidemiology 2012; 23: 699-705.

19. Puhó EH, Szunyogh M, Métneki J et al. Drug treatment during pregnancy and isolated orofacial clefts in hungary. Cleft Palate Craniofac J 2007. 44: 194-202.
20. Mølgaard-Nielsen D, Hviid A. Maternal use of antibiotics and the risk of orofacial clefts: a nationwide cohort study. Pharmacoepidemiol Drug Saf 2012: 21: $246-53$

21. Andersen JT, Petersen M, Jimenez-Solem E et al. Trimethoprim use in early pregnancy and the risk of miscarriage: a register-based nationwide cohort study. Epidemiol Infect 2013; 141: 1749-55.

22. Yang J, Xie RH, Krewski D et al. Exposure to trimethoprim/sulfamethoxazole but not other FDA category $\mathrm{C}$ and $\mathrm{D}$ anti-infectives is associated with increased risks of preterm birth and low birth weight. Int J Infect Dis 2011; 15: e336-41.

23. Goldberg O, Koren G, Landau D et al. Exposure to nitrofurantoin during the first trimester of pregnancy and the risk for major malformations. J Clin Pharmacol 2013: 53: 991-5.

24. Nordeng H, Lupattelli A, Romøren M et al. Neonatal outcomes after gestational exposure to nitrofurantoin. Obstet Gynecol 2013; 121: 306-13.

25. Crider KS, Cleves MA, Reefhuis J et al. Antibacterial medication use during pregnancy and risk of birth defects: National Birth Defects Prevention Study. Arch Pediatr Adolesc Med 2009; 163 978-85.

26. Erić M, Sabo A. Teratogenicity of antibacterial agents. Coll Antropol 2008; 32: 919-25.

27. Cooper WO, Hernandez-Diaz S, Arbogast PG et al. Antibiotics potentially used in response to bioterrorism and the risk of major congenital malformations. Paediatr Perinat Epidemiol 2009; 23. $18-28$

28. Santos F, Sheehy O, Perreault S et al. Exposure to anti-infective drugs during pregnancy and the risk of small-for-gestational-age newborns: a casecontrol study. BJOG 2011; 118: 1374-82.

29. Nørgaard M, Skriver MV, Sørensen HT et al. Risk of miscarriage for pregnant users of pivmecillinam: a population-based case-control study. APMIS 2008; 116: 278-83.

30. EUROCAT guide 1.3 and reference documents: instructions for the registration and surveillance of congenital anomialies. Antrim: EUROCAT Central Registry, 2005. www.eurocat-network.eu/ aboutus/datacollection/guidelinesforregistration/ guide1_3instructionmanual (21.12.2015).

31. Mylonas I. Antibiotic chemotherapy during pregnancy and lactation period: aspects for consideration. Arch Gynecol Obstet 2011; 283: 7-18.

32. Dolk H, Loane M, Garne E. The prevalence of congenital anomalies in Europe. Adv Exp Med Biol 2010; 686: 349-64

33. DSS Research. Calculators. www.dssresearch.com/KnowledgeCenter/ toolkitcalculators/statisticalpowercalculators.aspx (19.12.2014).

34. Shepard TH. «Proof» of human teratogenicity. Teratology 1994; 50: 97-8.
35. Källén BA, Otterblad Olausson P, Danielsson BR. Is erythromycin therapy teratogenic in humans? Reprod Toxicol 2005; 20: 209-14.

36. Nilsson MF, Webster WS. Effects of macrolide antibiotics on rat embryonic heart function in vitro. Birth Defects Res B Dev Reprod Toxicol 2014; 101 189-98.

37. Czeizel AE, Rockenbauer M. Teratogenic study of doxycycline. Obstet Gynecol 1997; 89: 524-8.

38. Czeizel AE, Rockenbauer M, Sørensen HT et al. The teratogenic risk of trimethoprim-sulfonamides: a population based case-control study. Reprod Toxicol 2001; 15: 637-46.

39. Larsen H, Nielsen GL, Møller M et al. Birth outcome and risk of neonatal hypoglycaemia following in utero exposure to pivmecillinam: a population-based cohort study with 414 exposed pregnancies. Scand J Infect Dis 2001; 33: 439-44.

40. Schaefer C, Peters P, Miller RK. Drugs during pregnancy and lactation. 3. utg. Amsterdam: Elsevier, 2014.

41. Nordeng H, Ystrøm E, Einarson A. Perception of risk regarding the use of medications and other exposures during pregnancy. Eur J Clin Pharmacol 2010; 66: 207-14

42. Larson L, Powrie R, File TM. Treatment of respiratory infections in pregnant women. www.uptodate.com/contents/treatment-ofrespiratory-infections-in-pregnant-women (3.12.2014)

43. Marrazzo J. Treatment of Chlamydia trachomatis infection. www.uptodate.com/contents/treatmentof-chlamydia-trachomatis-infection\#H49 (3.12.2014).

44. Patel BN, Lee UJ, Goldman HB. Urinary tract infections in women. London: BMJ Best Practice, 2013. http://bestpractice.bmj.com/best-practice/ monograph/77.html (21.12.2015)

45. Stensballe LG. Simonsen J, Jensen SM et al. Use of antibiotics during pregnancy increases the risk of asthma in early childhood. J Pediatr 2013; 162: 832-838.e3.

46. Nørgaard M, Ehrenstein V, Nielsen RB et al. Maternal use of antibiotics, hospitalisation for infection during pregnancy, and risk of childhood epilepsy: a population-based cohort study. PLoS ONE 2012; 7: e30850.

Mottatt 12.4. 2015, første revisjon innsendt 18.9. 2015, godkjent 21.12. 2015. En av forfatterne er redaktør i Tidsskriftet. Manuskriptet er derfor behandlet eksternt av setteredaktør Guri Rørtveit. 